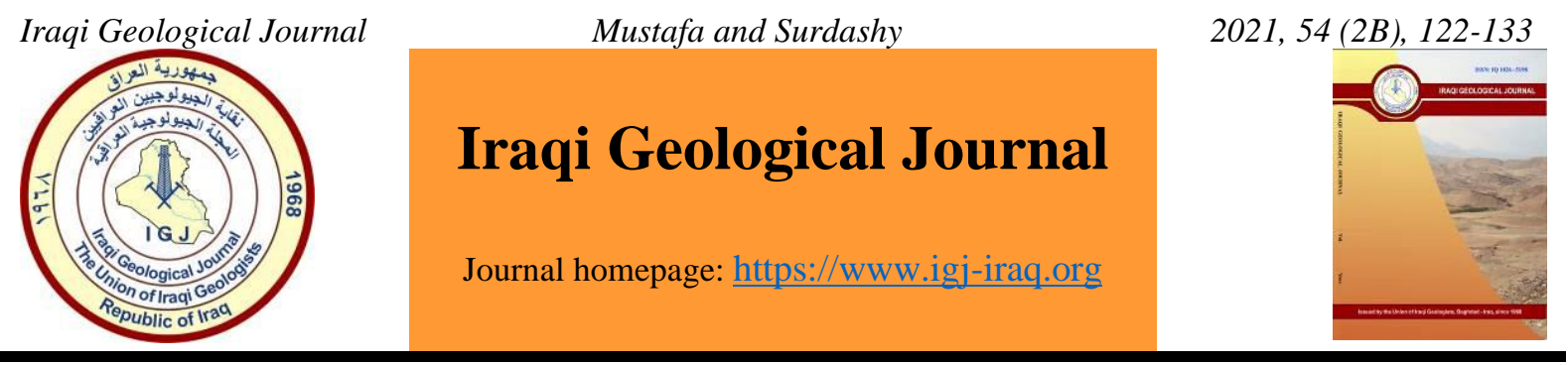

\title{
An Insight to the Sedimentological Developments of Quaternary Detritus Ring Fluvial Network, Altun Kupri Paleolake, NE IRAQ
}

\author{
Hisham Khalil Mustafa ${ }^{1, *}$ and Ali Mahmood Surdashy ${ }^{1}$ \\ ${ }^{1}$ Department of Geology, College of Science, Salahaddin University-Erbil, Kurdistan Region, Iraq \\ * Correspondence: Hisham.mustafa@su.edu.krd
}

Received: 25 March 2021; Accepted: 14 May 2021; Published: 31 August 2021

\begin{abstract}
During the Quaternary, an active basin in the shape of open lake originated along the Lesser Zab river at Altun Kupri area. The radial complex of fluvial deposit morphologically initiated by the coarse detritus material, that were transported by the Lesser Zab river and other surrounded valleys in a shape of delta towards the proximal part of coastal plain and the fine sediment to the distal part of it. The coarse one prograde along the fine gradually resulting in the accumulation of about $60 \mathrm{~m}$ thickness of continuous Pleistocene fluvial succession mostly of coarse grained sediments with minor sand, silt and clay intervals and some tongues and bands of calcareous mud. The bulk of basin fill is made of two depositional systems, the western and southwestern side was filled up by progradation delta systems, but the northern side was gradually filled up by fluvial sediment of Lesser Zab channel. The water impounded in this lake because of Awanah anticline as a ridge in front of the lake which is open with output channel that crosses the shallow gorge and the gorge became deeper and deeper gradually till the water drooped from the lake. There are several possibilities that this ring shape depression of Altun Kupri paleolake generated, first: the depression at Altun Kupri is formed as a result of dissolving lenses of Anhydrite and gypsum of the Fat'ha Formation beneath the northern limb of Awanah Anticline after the collapse of the cavity roof. second: the presence of ring shape cliffs of about $50 \mathrm{~m}$ thick and depression is bounded by $8 \mathrm{~km}$ in diameter of cross bedded conglomerates and sandstone and the third: the depression of Altun Kupri paleolake can be developed by meteoritic impact, with several sedimentological and structural evidence such as a delta distributary fan, and there was a hanging terrace at a high level along the gorge
\end{abstract}

Keywords: Altun Kupri; Kirkuk; Lesser Zab; Awanah; Quaternary; Paleolake; Flooding plain

\section{Introduction}

The Quaternary deposits of Iraq have been studied in general for soil investigation, hydrology, geomorphology, engineering geology, and archeology purpose. The river terraces and alluvial fan stages of the Mesopotamian zone have been studied by many authors like Aqrawi (2001), Al-Kaaby et al. (2020) and Al-Jaberi and Mahdi (2020). Also, the physical properties of Quaternary sediments of Erbil plain were studied by Bapeer et al. (2010) for engineering purposes. The Quaternary deposits in each province has its specific conditions, the studied area includes the foothills province in front of high Folded Zone, which is characterized by elongated and narrow structural ranges separated by broad and relatively shallow synclines. The Lesser Zab river deeply incised its path across many structures forming

DOI: 10.46717/igj.54.2B.11Ms-2021-08-31 
wide valley along which river terraces, flood plain and the relics of the old terrace are developed. The Quaternary deposits of Lesser Zab river and other surround valleys exposed at or closes to the surface in Altun Kupri basin and comprises up to 50m of ring shape cross stratified units with a special landscape features and elevation that appear to substantiate an ancient lake terrace. The Lesser Zab river deeply incised its path across many structures forming wide valley along which river terraces, flood plain and the relics of the old terrace are developed. The Quaternary sediments around the Lesser Zab river have been studied in two sections around Altun Kupri town (about $40 \mathrm{Km} \mathrm{NW}$ of Kirkuk city) along the ring shape of radial fluvial network (Fig. 1). This radial or arc shape modern fluvial network make a complex morphologic ridge. Lesser Zab distributaries' systems transported sediments from Zagros belt zone towards the southwest direction. The ancient lake deposits are best indicators of continental paleoclimatic changes during the Quaternary, led to development of various types of deposits which are differ widely in composition and extension depending on neotectonics, structure, and morphological condition. The main objective of this paper is to describe and interpret the aspect of deposition and morphotectonics in Altun Kupri paleolake basin along the Lesser Zab river at the late Quaternary period.

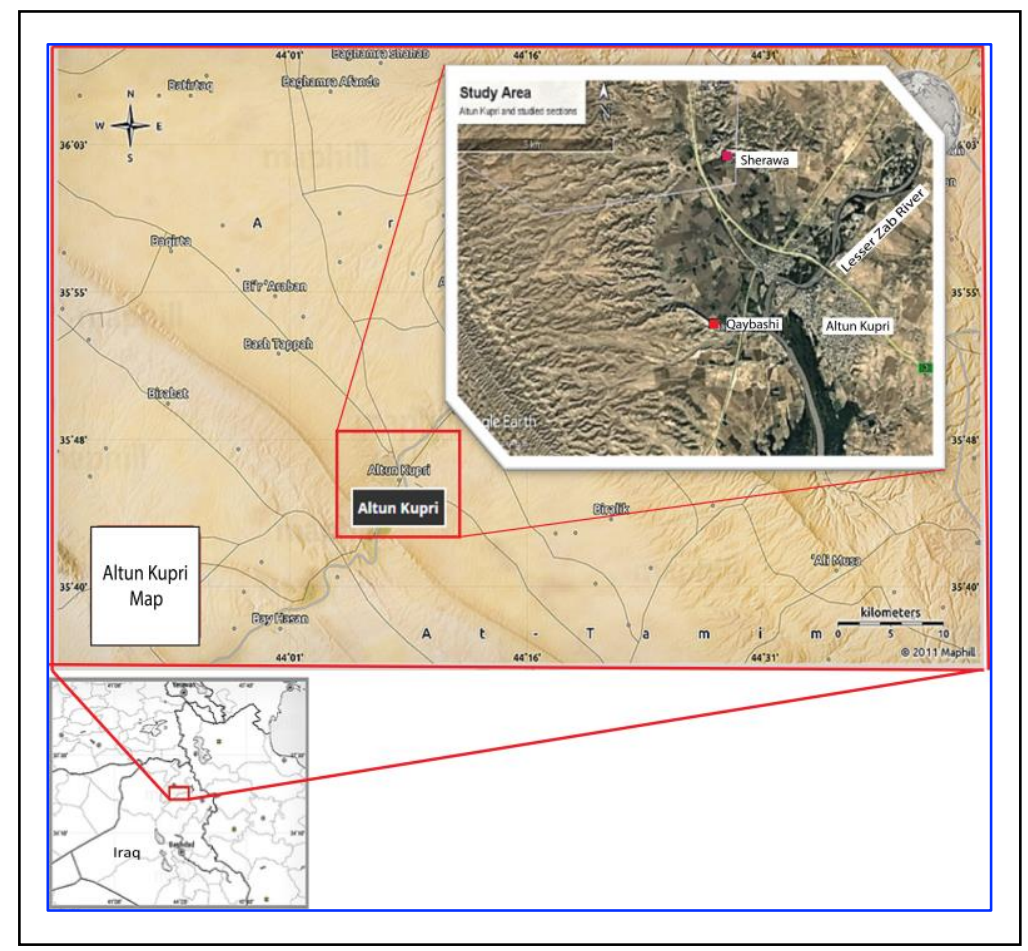

Fig.1. Location map of the study area

\section{Geological Setting of Altun Kupri and Surrounding Area}

The area around the Altun Kupri paleolake is mostly covered by recent deposits and Bai Hasan Formation of Late Pliocene, While the Mukdadiyah and Injana formations of Late Miocene-Early Pliocene are cover the distal part around the basin. Structurally the Awanah anticline which belongs to Low Folded Zone extends from southeast to northwest of Altun Kupri basin. The Surdash-TikritKubaisa deep Fault which has northeast-southwest trending passing perpendicular across Awanah anticline and divided it into two parts making a gorge along the path of Lesser Zab. Awanah anticline associated with reverse and normal faults (Jassim and Goff, 2006). A huge wide syncline extends along northeastern corner of Altun Kupri basin through Qashqa village (Fig. 2) and extends out of the studied area but located at catchment of Lesser Zab river. 
To complete our understanding of the main lithofacies of sediment inside the Altun Kupri paleolake, the structural condition and lithological information about the catchment area must be known. This area is a part of Low Folded Zone, its bounded by two main anticlines; Haybat Sultan to the north and Awanah to the south. These two anticlines are separated by a smaller and low relief folds; Bogd, Khalkhalan, Shiwashok, and Shiwasur. The largest part of these structures is covered by Pliocene deposits; Mukdadiyah and Bai Hassan formations which consist of conglomerate and claystone with subordinate sandstone and siltstone (Bapeer et al., 2010). The recent deposits scattered in the middle part of the catchment area consist of alluvial and river deposits. At the other narrow area near the northern and southern borders Fatha and Injana formations of Miocene age are cropped out, The Fat'ha Formation consists some beds of limestone and lenses of gypsum at the lower part but the upper part represented by alteration of red mudstone and silty claystone, lithologicaly. The Injana Formation comprises up to $450 \mathrm{~m}$ of fining upwards cycles of sandstone and reddish-brown mudstone. The sandstone beds are often strongly cross bedded and associated with channel lags and clay ball (AlHaidary, 2003). The same source terrain is also believed to have supplied the Pleistocene clastic lithofacies sediments of the Altun Kupri paleolake.

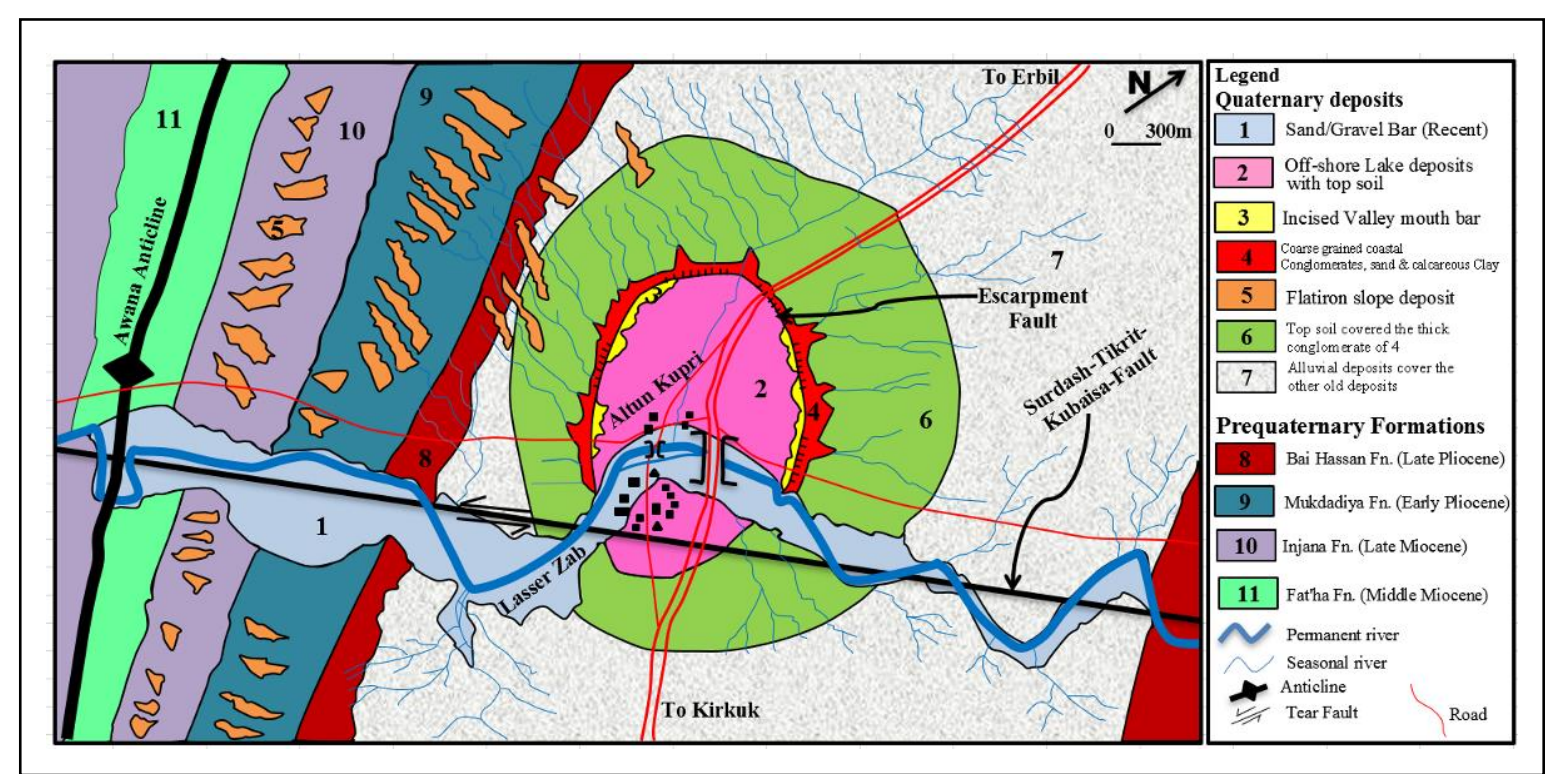

Fig. 2. Geological map of the study area

\section{Materials and Methods}

Two sections are chosen for study, the first is Sherawa section and the second is Qaybashi section, each section is studied in detail and (22) samples are collected from the two sections (for impending petrographic studies). The paleocurrent analysis also were studied in order to determine the ancient flow direction of the current. The geological map of the study area was constructed based on the data collected from the field. Also the columnar sections are constructed with the hypothetical block diagram of Altun Kupri paleolake.

\section{Results}

\subsection{Developing of Open Basin Lake in Low-Lying Area}

The Altun Kupri paleolake is an open lake that was originated during Quaternary along the flow path of Lesser Zab river. The high discharge of river and the open condition of this lake can be expressed to have left an imprint upon the sedimentary facies which are accumulated sediments of siliciclastic 
origin. Because of its location, terrigenous permanent lakes are commonly found today in low folded mountainous terrain where high precipitation, and sediment run off are combined together to make a complex of facies with different structure (Selley,1988). More and more towards the external part of Foot hill zone The Lesser Zab flow velocity decreases and forming a lake behind Awanah anticline in a shape of foreland basins by presence of bowl shape depression, which acted as domains for syndepositional shallow-water clastic sedimentation along the coastal plain of open lake.In other part of Lesser Zab upstream catchment area Gnau characeae-derrived carbonate-rich freshwaters deposeted in Gnau paleolake,(Khanaqa et al., 2013). The exposed sediment along the coastal area of this lake was mainly supplied by Lesser Zab river from a huge catchment area, and other surrounding seasonally drainage basins exert influence on the input of sediment from the southern side of the lake which has a steep slope along the northern limb of Awanah anticline (Fig. 3). One of the characteristic features during the late Quaternary of Altun Kupri lake is the tendency for lake level fluctuation and gradual drawdown, till the water dropped under the influence of strike slip fault that was presented along Awanah anticline which is located in front of the lake (Fig. 2). This fault led to make a deep incision gradually through the gorge on the path of lake outlet. During this time, the shoreline was unstable because the inflow of Lesser Zab river and the other valleys around the lake, in addition to that, the precipitation was not balanced by outflow from one channel through a fault plain along Awanah anticline because the rate of erosion by the water flow of the lake outlet along the weak zone gorge of fault plain was higher than the rate of upward movement by new tectonic activity. This condition may nevertheless be the main cause of water loss, that inducing considerable gradual lake level falling. It is probable that many ancient lake basins also oscillated between open and closed conditions. Such variations can be expected to have left an imprint upon the sedimentary facies (Reading,1980). In the other area in High Folded Zone the evidences of a Quaternary lakeare found in the Mawat-Chwarta vally NE-iraq (Khanaqa et al., 2014).

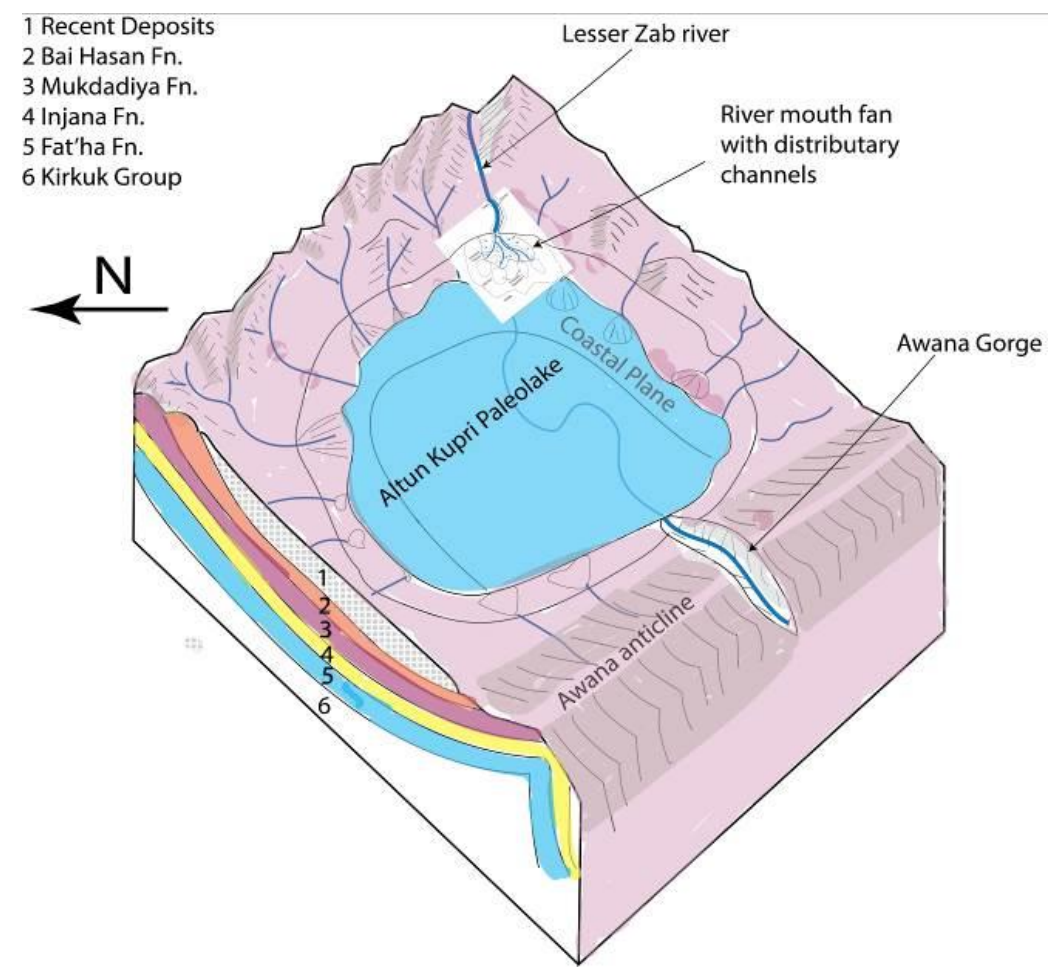

Fig.3. Hypothetical block diagram of Altun Kupri paleolake

The exposed sediment along the coastal area around the bowl shape depression that was deposited by the Lesser Zab river, as a delta distributary channels may be severally affected by subaerial 
weathering after dropping the impound water. As the costal processes continue through time by the Lesser Zab river and other streams migrate their loads from the distributary channels towards the coastal plain and the deeper parts so the sediment rapidly became finer grained. A characteristic sequence of coarse grain size and sedimentary structures it may occurred in crudely bedded or cross bedded sequences (Allen,1970), this condition is measurable in two columnar sections towards the upper part. In Sherawa and Qaybashi sections (Fig. 1) along the ring shape ridge, these sequences are fan shaped and wedge shaped prograde up to 6-8 $\mathrm{km}$ around the ring-shaped bowl depression of Altun Kupri paleolake. Colella (1988) mentioned that, wedge-shaped or set-like forms of lake coastal system developed that are relatively thin as a result of changes in base level or climate, (Fig. 4).

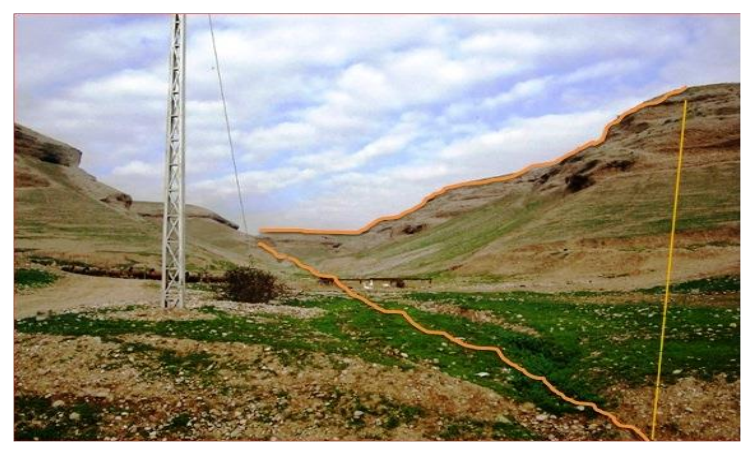

Fig. 4. One of incised valleys along the wedge-shaped costal deposit of delta plain at northern part

The most important evidences and indicators for forming this lake in this location are:

- At the present, the Lesser Zab river cross-cutting the Awanah anticline through a deep gorge perpendicularly, but during the last stage of Zagros orogeny at Pleistocene which cause uplifting of Awanah anticline, the condition was impounding the water in a bowl shape open lake with output channel that crosses the shallow gorge(pit) which was formed along the cross-cut fault with many hanging terraces at high level along the gorge. The area had suffered from new tectonic movement and the gorge became deeper and deeper gradually till the water drooped from the lake.

- The current dry lake presented as a depression with circle or ring shape, the flat floor of its basin is infilled by fine grained lake deposits which is laid down in deeper water and now covered by recent alluvial sediments which is make a huge plain of fertile agricultural land.

- The main karstified rocks (in Iraq) are gypsum and limestone and they presented in the Fat'ha Formation (Middle Miocene), The forms of sinkholes in gypsum beds, are very irregular in shape and in dimensions, the shape is mainly irregular, formed due to enlargement of joints and dissolving of the top layer, which means it is formed due to collapse of the top layer after the dissolving of the underneath rocks (Sissakian and Al-Mousawi, 2007). The bowl shape depression at Altun Kupri may be formed as a result of lenses of anhydrite and gypsum of Fat'ha Formation beneath the northern limb of Awanah Anticline, after the collapse of the roof.

- The depression is bounded by ring shape cliffs of about $50 \mathrm{~m}$ thick and $8 \mathrm{~km}$ in diameter of cross bedded conglomerates and sandstone that deposited near the shore in fresh water along the coastal plain of the lake. The ring shape deposits remain as an escarpment around the depression and has a wedge shape thick frontage around the bowl shape depression and thin hind part (back water of lake).

- There is a possibility that this ring shape depression of Altun Kupri paleo lake can be developed by meteoritic impact but there are no distinct indications were found to prove it, because the rate of erosion in this area was high.

- Along the coastal area around the bowl shape depression that was deposited by the Lesser Zab river, as a delta distributary fan rapidly become finer grained with increasing distance from the fan 
apex laterally, and along the vertical section of ridge the mound deposit of costal part coarsening upward by progradation of delta shape sediment towards the lake epicenter during gradational dropping of water through the incised gorge of Awanah.

\subsection{Lateral and Vertical Profiles of Foot Wall Coarse Grained Delta}

Vertical facies sequence models have been constructed for many coarse-grained coastal systems along ring shape foot wall scarp slop type (Figs. 5 and 6). Fan delta of Lesser Zab and other valleys tend to form thick sequences in a circle shape area with a diameter less than $10 \mathrm{~km}$, prograde up to $5 \mathrm{~km}$ in a wedge shape (Fig. 7). The fan shaped or possibly wedge-shaped delta system with very thin sequence that thicken towards the fault scarp are growth on coastal plain of lake (Reading, 2004). Sediments along the scarp shape mound are generally a complex mixture of river-derived detritus, clastic material cannibalized from older exposed out crop of different formations at a huge catchment area.

In the field, the further advanced form of terrigenous succession represented as a ring shape escarp around the flat plain (Fig.7). The conglomerate change gradually to brown sandstone and light brown calcareous mudstone with a thickness about $8 \mathrm{~m}$. The environment of this unit can be allocated as subaqueous and subaerial delta plain which contain mud cracks (Fig. 8). The distributary channels on the plain can be determined as lenses of sandstone beds as a lateral change. The explanation of Haq (1991) can be accepted for altenation of conglomerate to sand to cracked calcareous mud overlaid by argillaceous conglomerate in this succession laterally and vertically.

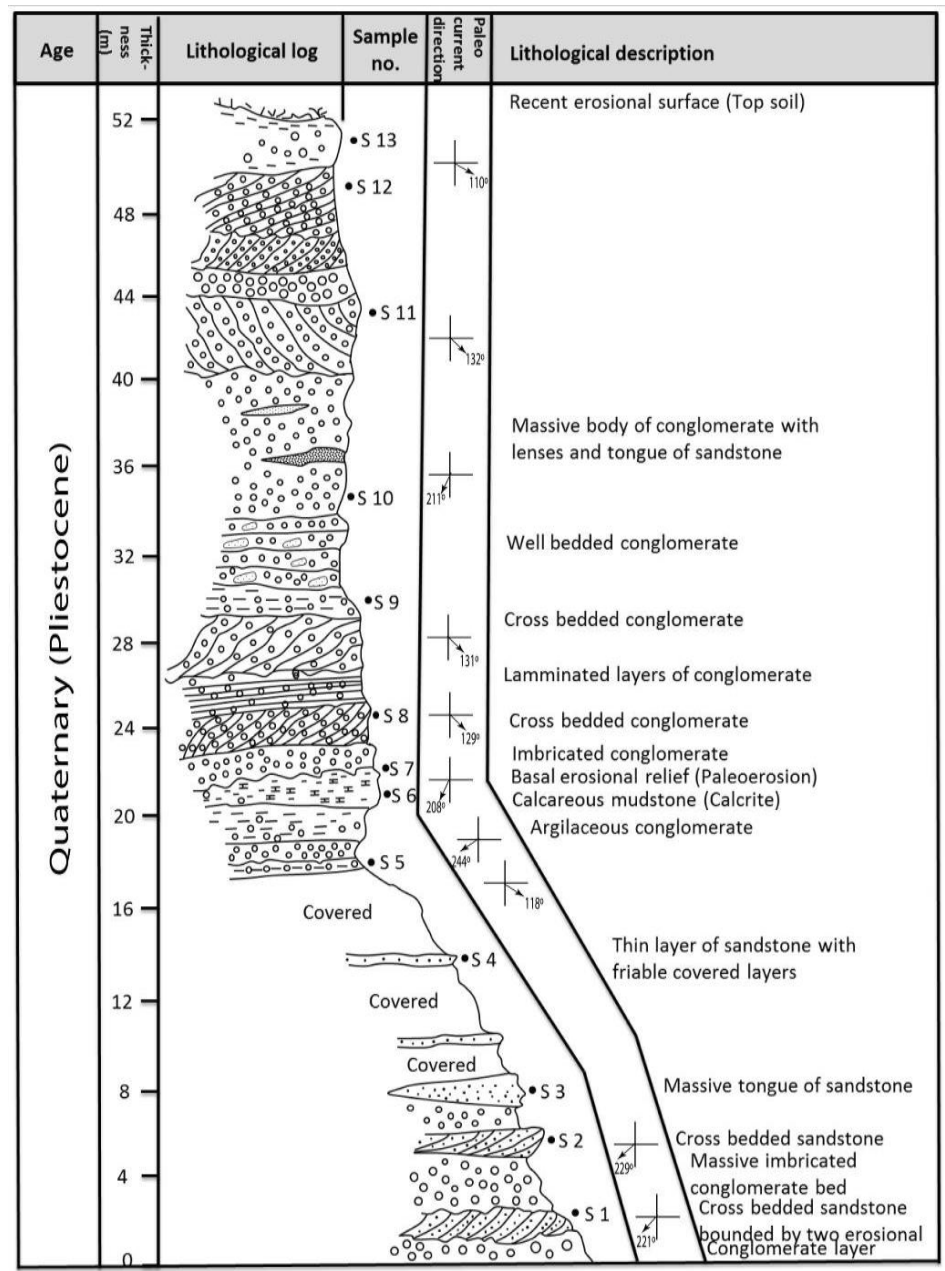

Fig.5. Columnar section of Sherawat area 


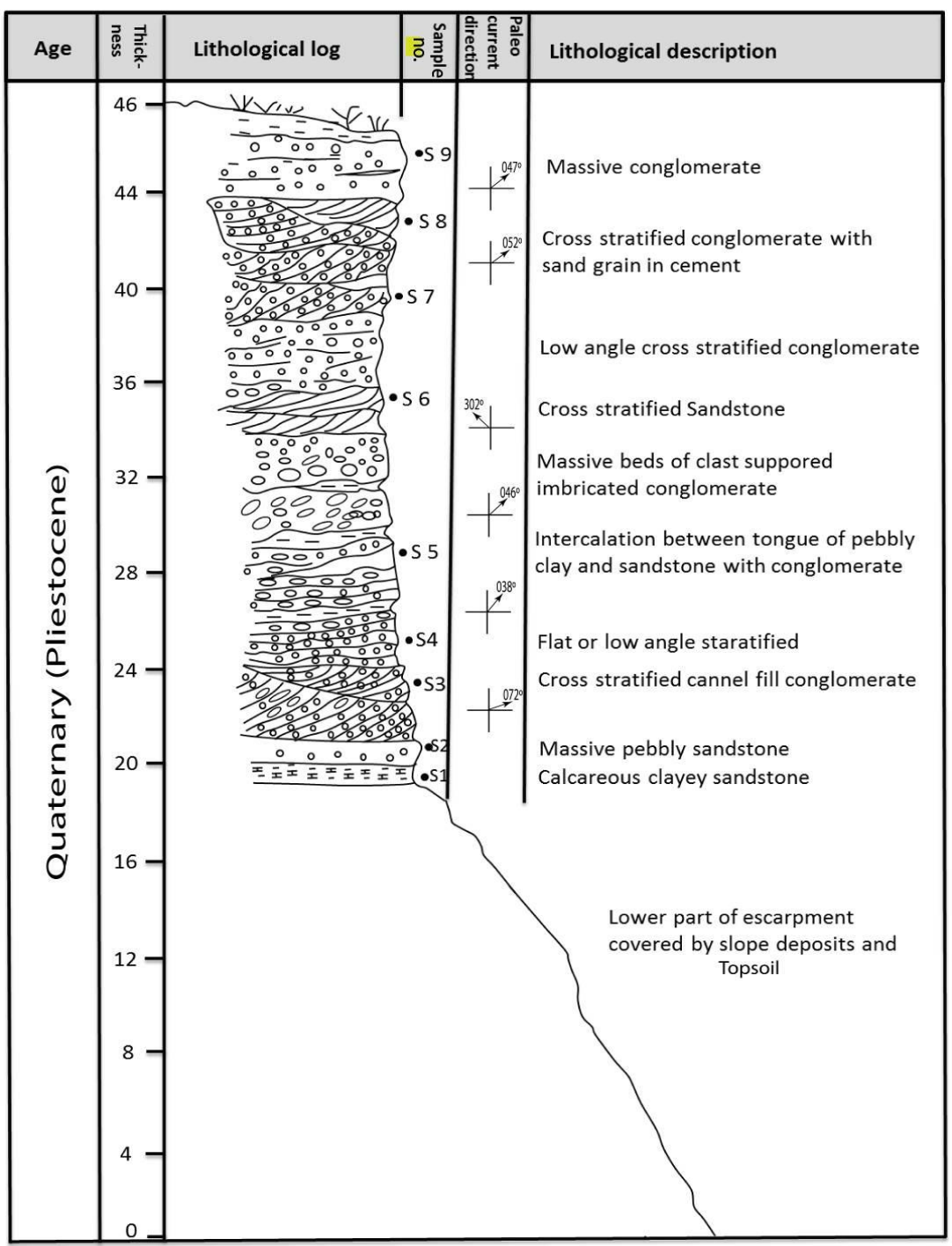

Fig.6. Columnar section of Qaybashi area

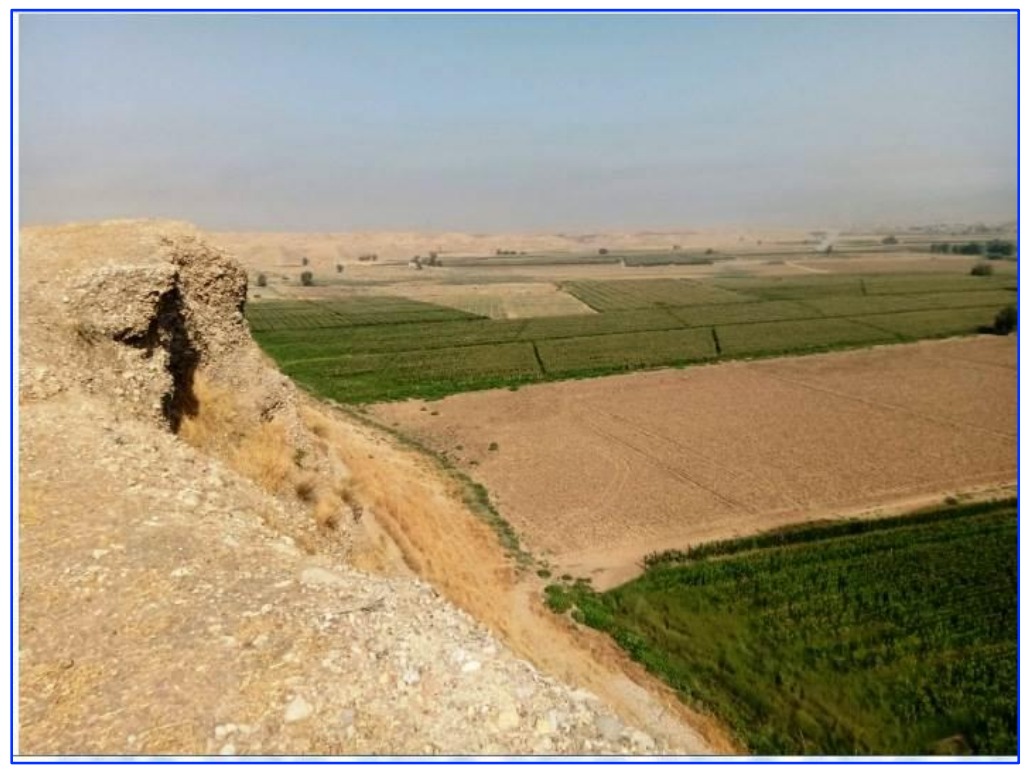

Fig.7. Ring shape ridge of terrigenous deposits and flat plain as a center of lake 


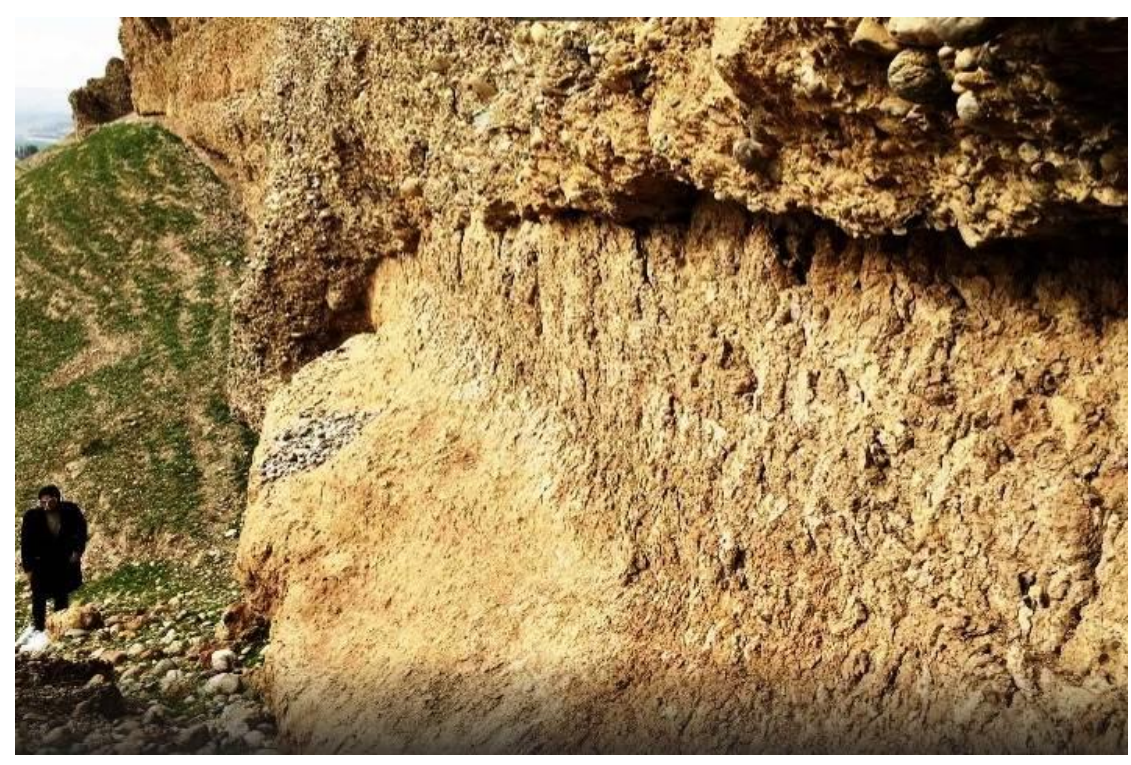

Fig.8. Subaerial cracked mudstone overlaid by sand layer and argillaceous conglomerate

\subsection{Sedimentary Structures}

Along the exposed ring-shaped ridge around Altun Kupri basin, a sequence is dominated by fluvial deposits clasts which are of intraformational or extraformational origin, usually form matrix-supported conglomerates (paraconglomerate) and clast supported conglomerate (orthoconglomerate) texture. Such conglomerates, commonly those with horizontal stratification and clast imbrication as a lag on channel floors or characterized by lenticular bedding and erosion surfaces with conspicuous relief in some horizons. Some conglomerates especially show trough or tabular cross bedding (Fig. 10). Evidence of water stage fluctuations occurs, as erosional and reactivation surfaces, sometimes include relief show migration of river channel behavior, flooding plain and drainage conditions under the role of external controls such as tectonics, climate, and base level. The study sedimentary structures are a best method to analyzing and interpreting depositional environments., unlike sediments of different kind of grains and textures, and ground mass. They unequivocally reflect the environmental process that laid down the particle of sediment.

\subsubsection{Cross Bedding}

Cross-stratification consists of the arrangement of sediment strata deposited at one or more angles to the main stratification. Cross-stratification produced by dunes and unit bars is the most common sedimentary structure in sandy river-channel deposits (Bridge, 1997). Cross-bedding analysis is important as it helps the understanding of sedimentary deposits and may be used to understand flow direction, flow velocity, flow character and water depth during the deposition of sediments. The crossbedding in the coastal plain of paleolake in each distributary channels has different directions (Fig. 9) The cross bedding is a widespread sedimentary structure in study area; therefore, it was used for paleocurrent interpretation (Fig. 10). 


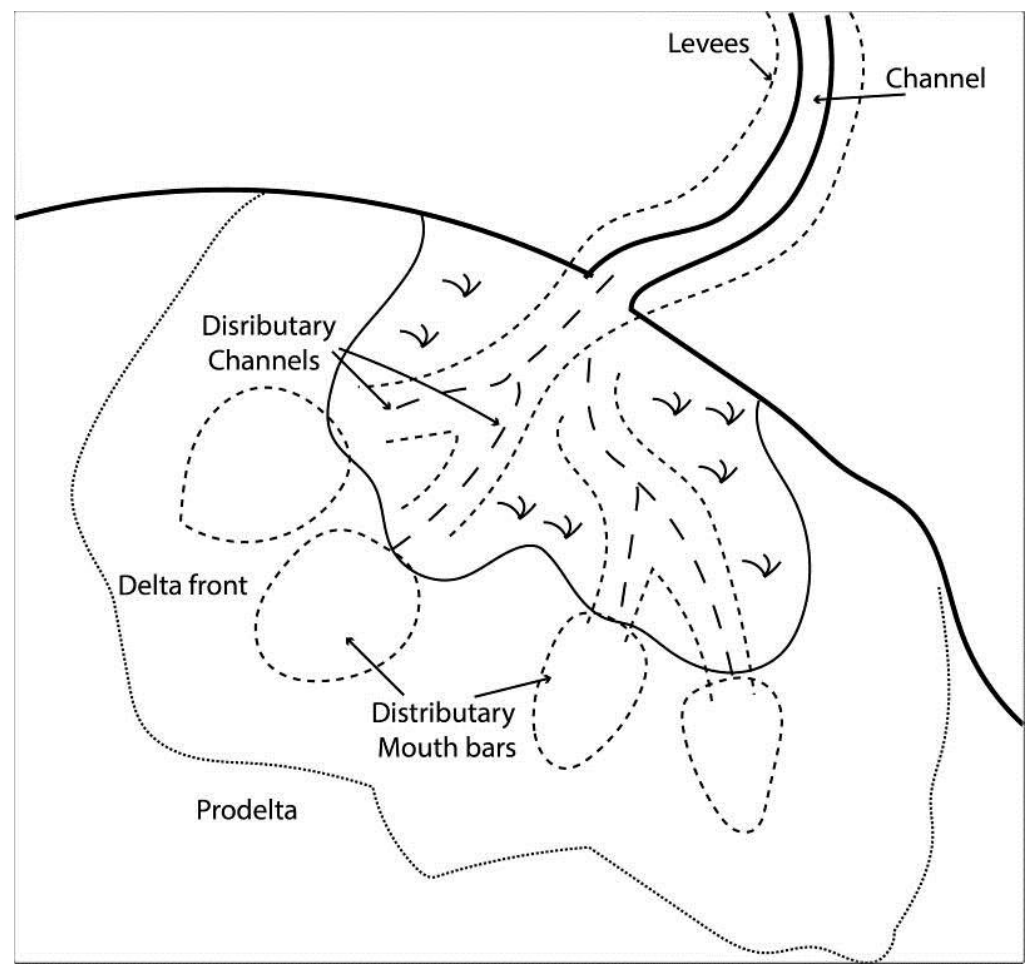

Fig.9. Distribution of sediment along the coastal plain of paleolake during dispersion of mouth load by distributary channels at delta front.

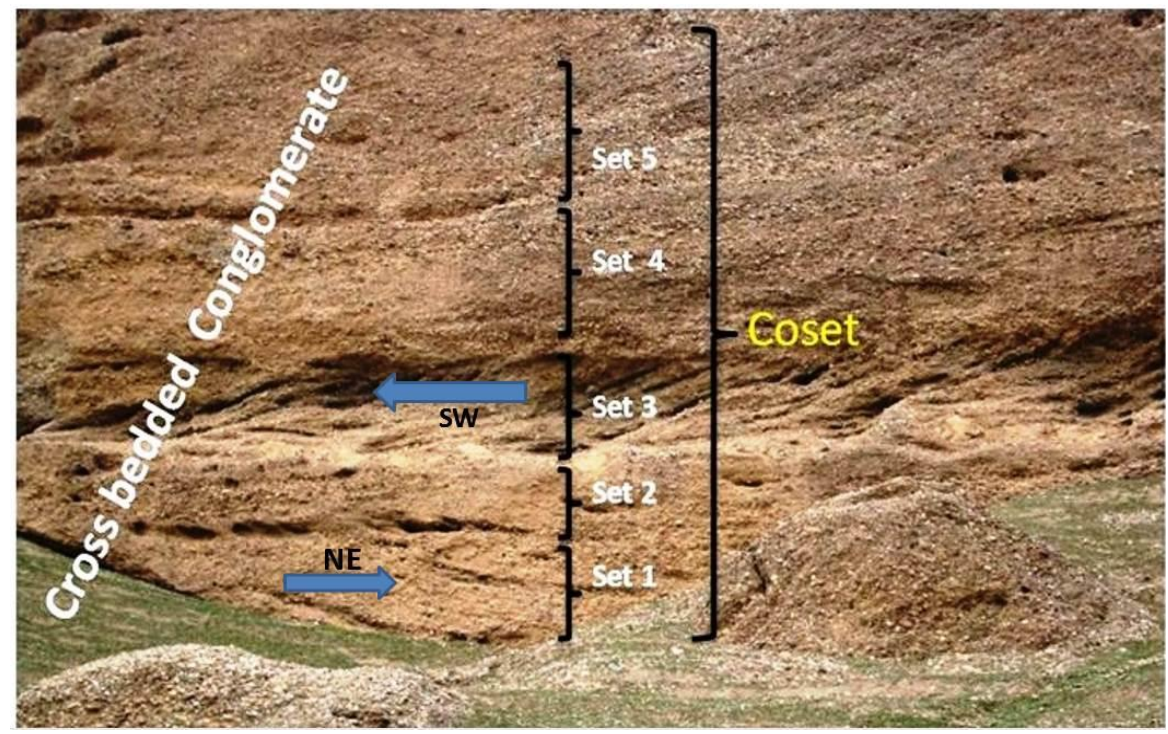

Fig.10. Cross strata set and cosset, with lateral and vertical change in direction because of different direction flow of river mouth abutments (distributary channels)

\subsubsection{Imbrication}

Clast imbrication is one of the most conspicuous sedimentary structures in coarse-grained clastic deposits of modern rivers but also in the stratigraphic record, the clast imbrication refers to a depositional fabric where sediment particles of similar sizes overlap each other, similar to a run of toppled dominoes (Schlunegger and Garefalakis, 2018).

In Lesser Zab river mouth or debouchment on the lake, usually the dips of pebbles toward the upstream. There is a difference in directions of pebbles along the imbricated pebbles and cross strata of 
ring shape ridge of coastal plain of paleolake. The reason of this diversity in direction of water flowing is because of difference in direction of distributary channels (Figs. 9 and 11). In some cases, a form of reversely oriented particle develops when wedge-shaped pebble are subject to sheet flow. The thick end of the pebble has more mass on the underlying surface. If the weight produces adequate friction along the underlying surface, the thin edge of the pebble could be moved by the current, pivoting like a rudder about its post pointing downstream. Such orientations might be expected on large particles after sudden extreme floods such as the floods that formed the large abutment sediment body in tributary channels of delta plain of Altun Kupri paleolake.

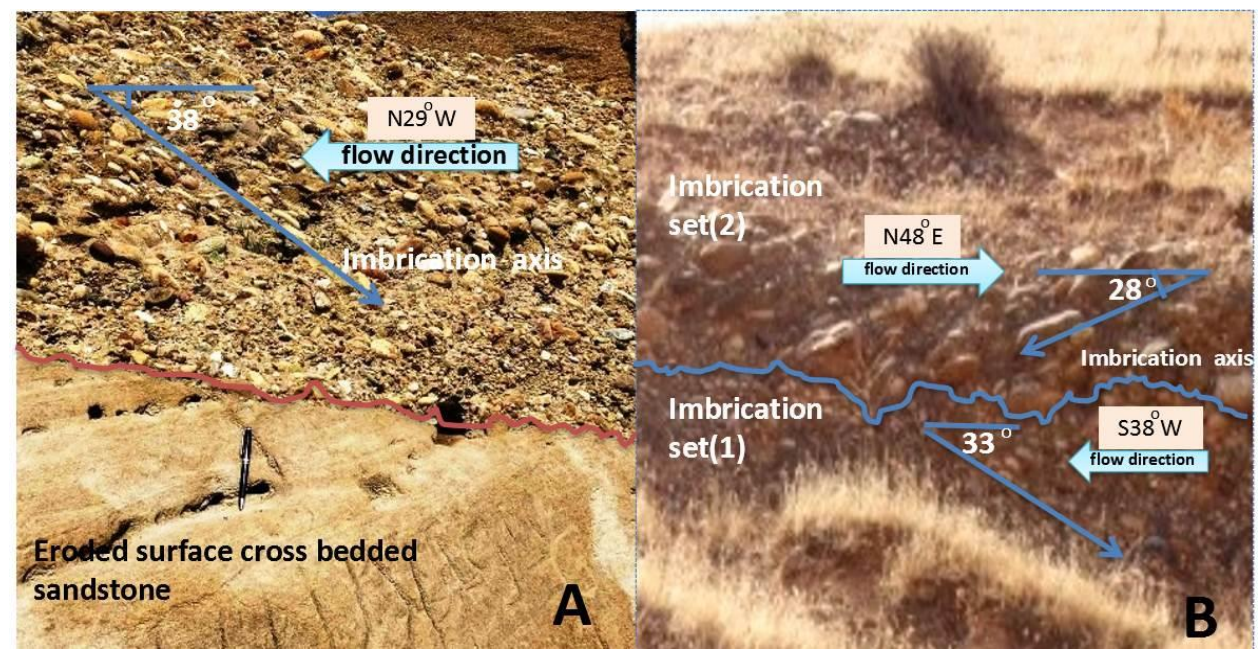

Fig.11. Imbrication of conglomerate grain generated by flow of water. A-In conglomerate bed underlain by cross bedded sandstone. B-In two different directions of flow

\subsubsection{Load Structures}

Load structure is a soft-sediment deformation structures generally, the production of load structures calls for the process of trigger mechanisms, deformation mechanisms and driving mechanisms (Allen, 1982; Harris et al., 2000). The vertical succession should see as beds of high bulk density like sands overlying those of lower density like muds, it is well known that muds, with a comparatively high-water content during deposition, have a significantly lower bulk density than sands, which are deposited with a closer packing.

\subsubsection{Mud Cracks}

It is a generally arising phenomenon that Shrinkage often leads to cracking in clay soils as a result of consistent moisture loss, cracking usually occur when soils are restrained while undergoing shrinkage, which generates high negative pore pressure otherwise known as soil suction, within the drying soil mass, the desiccation cracking can induce detrimental impacts in cohesive soils, such as reduction in the strength, stiffness, stability of the overall soil mass, and also an increase in the compressibility and soil hydraulic properties (Bamgbopa, 2016).

Shoreline deposits of lake range from well-developed spits and bars to thin sheets of rippled sand or imbricated pebbles. Flooding, and desiccation. Deltaic deposits include delta fronts separated by subaerial surfaces. Where alluvial fans impinge on lake margins, the boulders and cobbles may be imbricated by uniflow direction forming tabular sets that dip lakeward. Thick muddy floodplains are disrupted by complex desiccation cracks sand may fill desiccation cracks. (Fig. 12). 


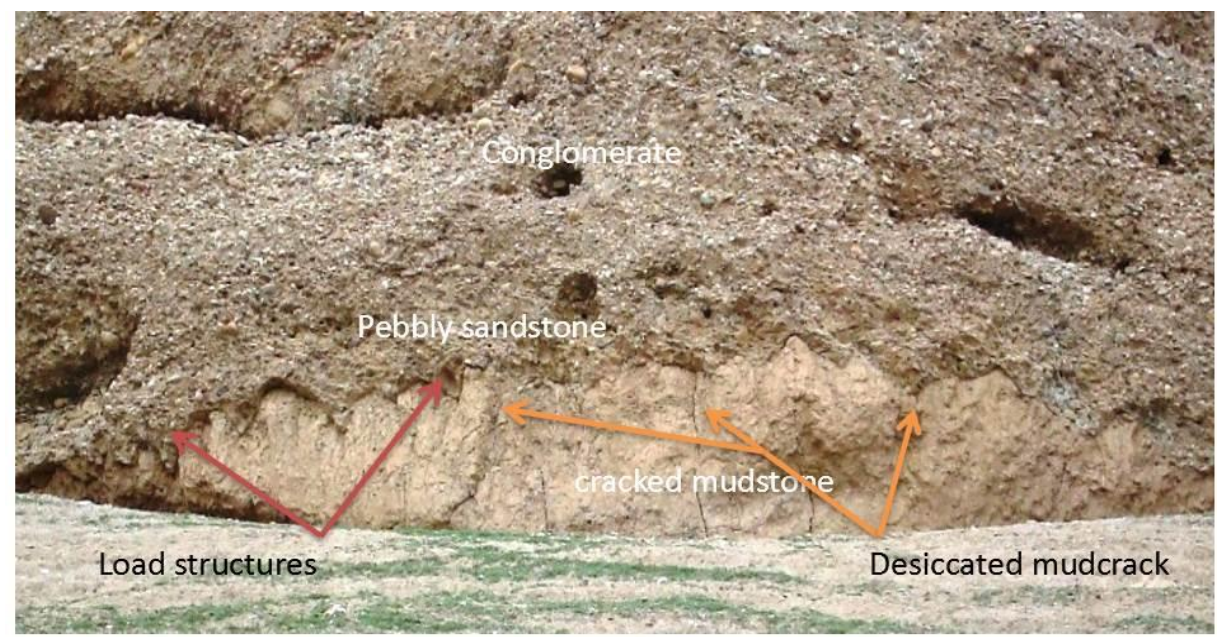

Fig.12. Loadcast structure at Sherawa section with desiccated mud cracks

\section{Conclusions}

- Altun Kupri paleolake is an open lake that was originated at Quaternary (Pliestocene) along the flow path of the Lesser Zab river. The high discharge of the river and the open condition of this lake can be expressed to have left an imprint upon the sedimentary facies which are accumulated sediments of origin.

- During this time shoreline was unstable because the inflow of Lesser Zab and other valleys around the lake plus precipitation is not balanced by the outflow from one channel through a fault plain along Awanah anticline because the rate of erosion by the water flow of lake outlet along the weak zone gorge of fault plain is higher than the rate of upward movement by new tectonic activity.

- The siliciclastic deposits of ring shape paleolake make a cliff of about $50 \mathrm{~m}$ thick and $8 \mathrm{~km}$ in diameter of cross bedded conglomerates and sandstone that deposited near the shore in fresh water along the coastal plain of the lake. The ring shape deposits remain as an escarpment around the depression and has a wedge shape thick frontage around the bowl shape depression and thin hind part (back water of lake).

- The exposed sediment around the depression that was deposited by the Lesser Zab river, as a delta distributary channels may be severally affected by subaerial weathering after dropping the impound water. As the coastal processes continue through time by the Lesser Zab river and other streams migrate their loads from the distributary channels towards the coastal plain and the deeper parts so the sediment rapidly became finer grain.

- There is a possibility that this ring shape depression of Altun Kupri paleolake can be developed by meteoritic impact but there are no distinct indications were found to prove it, because the rate of erosion in this area was high.

- The bowl shape depression at Altun Kupri is possible to be formed as a result of dissolution the lenses of anhydrite and gypsum of Lower Fars Formation beneath the northern limb of Awanah anticline.

- The main sedimentary structures that remain as a relic to prefer water flow activity of river mouth and distributary cannels at costal area of the lake such as cross bedding, imbrication, load cast and mud cracks. 


\section{Acknowledgements}

The authors are very grateful to the Editor in Chief Prof. Dr. Salih M. Awadh, the Secretary of Journal Mr. Samir R. Hijab and the Technical Editors for their great efforts and valuable comments.

\section{References}

Al-Haidary, S., 2003. Sedimentological study of Injana Formation in Erbil Governorate. Unpublished M.Sc. Thesis, Salahaddin University-Erbil, Iraq (in Arabic,), 124pp.

Al-Jaberi, M.H. and Mahdi, M.M., 2020. Mineralogy and paleontology of the Quaternary Sediments in Karmat Ali at Basrah, Southern Iraq. Iraqi Geological Journal,105-120.

Al-Kaaby, L.F. and Al-Badran, B.N., 2020. Minerals and sedimentary characteristics of Quaternary sediments of different regions in Southern Iraq. Iraqi Geological Journal, 68-89.

Allen, J.R.L.,1970. A Quantitative model of grain size and sedimentary structures in lateral deposits. Iraqi Geological Journal, 7(1), 129-146.

Allen, J.R.L., 1982. Sedimentary structures: their character and physical basis. Vol. I. Elsevier, Amsterdam, 593 pp.

Aqrawi, A. A. M., 2001. Stratigraphic signatures of climatic change during the Holocene evolution of the TigrisEuphrates delta, lower Mesopotamia. Global and Planetary Change, 28, 267-283.

Bamgbopa, O.S., 2016. Investigation of shrinkage and cracking in clay soils under wetting and drying cycles. International Journal of Engineering Research \& Technology (IJERT), 5(11), 283-320.

Bapeer, G.B., Surdashy, A.M. and Hassan, K.M., 2010. Infiltration rates of soils in some locations within Erbil Plain, Kurdistan Region, North Iraq. Iraqi Bulletin of Geology and Mining, 6(2),127-137.

Bridge, J. S., 1997. Thickness of sets of cross strata and planar strata as a function of formative bed-wave geometry and migration, and aggradation rate. Geology, 25(11), 971-974.

Colella, A., 1988. Pliocene-Holocene fan deltas and braid deltas in the Crati Basin, southern Italy: a consequence of varying tectonic conditions. In: Nemec, W., Steel, R.J. (Eds.), Fan Deltas: Sedimentology and Tectonic Settings. Blackie And Son, Glasgow, 50 -74.

Haq, B.U., 1991. Sequence stratigraphy, sea-level change, and significance for the deep sea. Sedimentation, Tectonics and Eustasy: Sea-Level Changes at Active Margins,1-39.

Harris J. R., Wilkinson, L., and Grunsky, E.C., 2000. Effective use and interpretation of lithogeochemical data in regional mineral exploration programs: application of Geographic Information Systems (GIS) technology. Ore Geol.16,107-143.

Jassim S. Z., and Goff, J.C. 2006. Geology of Iraq. Dolin, Prague and Moravian Museum, Brno.

Khanaqa, P.A., Karim, K.H. and Thiel, V., 2013. Characeae-derived carbonate deposits in Lake Ganau, Kurdistan Region, Iraq. Springer, Facies, 59, (4), 653-662,

Khanaqa, P.A., Karim, K.H. and Riegel, W., 2014. Evidence of a Quaternary dammed Lake in the MawatChwarta area, Western Zagros, Kurdistan Region, NE-Iraq. Elsevier,125, 74-81,

Martinez J.M., 2015. Architecture and origin of fluvial cross-bedding based on flume experiments and geological examples field case studies: Rillo de Gallo, Spain and Northumberland, UK, Ph.D. thesis, University of East Anglia,442p.

Owen, G., 1995. Soft-sediment deformation in upper Proterozoic Torridonian sandstones (Applecross Formation) at Torridon, northwest Scotland. Journal of Sedimentary Research, 65(3a), 495-504.

Reading, H.G., 1980. Characteristics and recognition of strike-slip fault systems. Sedimentation in oblique-slip mobile zones, 4, 7-26.

Reading, H. G., 2004. Sedimentary environments: processes, facies and stratigraphy, 3rd edition, Blackwell, 688 pp.

Schlunegger, F. and Garefalakis, P., 2018. Clast imbrication in coarse-grained mountain streams and stratigraphic archives as indicator of deposition in upper flow regime conditions. Earth surface dynamics, 6(3), 743-761.

Selley, R.C., 1988. Applied Sedimentology, Academic Press, London. 448 pp.

Sissakian, V.K. and Al-Mousawi, H.A., 2007. Karstification and related problems, examples from Iraq. Iraqi Bulletin of Geology and Mining, 3(2), 1-12. 